\title{
Isolation and characterization of $\mathrm{N}$-fixing and IAA producing rhizobacteria from two rice field agro-ecosystems in South Sulawesi, Indonesia
}

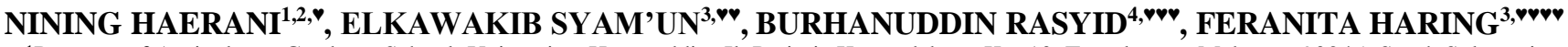 \\ ${ }^{1}$ Program of Agriculture, Graduate School, Universitas Hasanuddin. Jl. Perintis Kemerdekaan Km.10, Tamalanrea, Makassar 90245, South Sulawesi, \\ Indonesia. Tel.: +62-411-587064, "email: nininghaerani06@gmail.com \\ ${ }^{2}$ Program of Agrotechnology, Faculty of Agriculture, Animal Science and Forestry, Universitas Muslim Maros. Jl. Dr. Ratulangi no. 62 Maros, South \\ Sulawesi, Indonesia \\ ${ }^{3}$ Departemen of Agrotechnology, Faculty of Agriculture, Universitas Hasanuddin. Jl. Perintis Kemerdekaan Km. 10, Tamalanrea, Makassar 90245, South \\ Sulawesi, Indonesia. Tel.: +62-411-587064, “wemail: elkawakib@yahoo.com, vwvemail: feraharing20@gmail.com \\ ${ }^{4}$ Department of Soil Science, Faculty of Agriculture, Universitas Hasanuddin. Jl. Perintis Kemerdekaan Km. 10, Tamalanrea, Makassar 90245, South \\ Sulawesi, Indonesia. Tel.: +62-411-587064, ${ }^{v v v e m a i l: ~ b u r r a s y i d @ u n h a s . a c . i d ~}$
}

Manuscript received: 8 December 2020. Revision accepted: 9 April 2021.

\begin{abstract}
Haerani N, Syam'un E, Rasyid B, Feranita. 2021. Isolation and characterization of N-fixing and IAA producing rhizobacteria from two rice field agro-ecosystems in South Sulawesi, Indonesia. Biodiversitas 22: 2497-2503. Nitrogen-fixing bacteria that live in the rhizosphere are microorganisms that can increase $\mathrm{N}$ availability for rice plants in a non-symbiotic manner. Nitrogen-fixing bacteria also support growth through the production of growth hormones. These abilities are mainly influenced by the environment and their association with plants. This research aims to determine the microbial characteristics from two different rice fields agro-ecosystems (rainfed and irrigated) in South Sulawesi. Bacteria isolated from the rhizosphere soil of rice in six districts were cultured and isolated using Burk's N-free media for screening purposes. A total of 20 isolates were observed for their morphological and biochemical properties, determined their ability to fix nitrogen and produce IAA. The results showed that all isolates could grow on nitrogen-free media, in which 13 isolates were isolated from rainfed rice fields, and 7 isolates were from irrigated rice fields with various physical and biochemical properties, all other qualities tested also varied. NG4 isolate from Gowa Regency (rainfed rice field) produced the highest nitrogen $(0.157 \%)$, and NB13 isolate from Barru (rainfed rice field) had the highest concentration of growth hormone (IAA) (1,835 mg $\mathrm{L}^{-1}$ ). All isolates obtained from rainfed rice fields showed a better ability to fix nitrogen and produce growth hormone than those from irrigated rice fields. Bacteria isolates from rainfed rice fields have higher biofertilizers and biostimulant capacity to develop environmentally-friendly rice cultivation.
\end{abstract}

Keywords: IAA, irrigated and rainfed rice fields, nitrogen fixation, rhizobacteria

\section{INTRODUCTION}

Continuous use of land, especially for rice cultivation, will have an impact on decreasing land quality and productivity. The subsequent land management through fertilization often leads to a decrease in organic matter and fertility. It also affects soil physicochemical, biochemical, and microbiological properties. Inorganic nitrogen sources, such as urea, often reduce land efficiency when applied and are not organically bound to $\mathrm{N}$; therefore, the plant becomes deficient in nitrogen (Witte 2011). However, biological approaches to improve soil quality and fertility will increase rice production and reduce synthetic fertilizers consumption (Sun et al. 2019). It also reduces the environmental problems associated with the excessive use of fertilizers. Therefore, improving biological nitrogen fixation on rice fields is very important (Ma et al. 2019).

The use of non-symbiotic nitrogen-fixing bacteria as a biofertilizer agent has been widely developed in agriculture (Pereg et al. 2018). The relevance of manure is increasing rapidly because chemical fertilizers damage the environment (Vinten et al. 2002; Tahovská et al. 2013).
However, biological fertilizer leads to soil enrichment, long-term sustainability, and environmentally friendly products (Shridhar et al. 2012).

Nitrogen comprises about $78 \%$ of the atmosphere's gases; however, plants do not use it directly, although it is abundant in the air (Rascio and La Rocca 2018). Therefore, chemical or biological processes are needed to convert $\mathrm{N}$ gas into forms utilized by plants (Dong et al. 2019). Soil bacteria carry out the natural fixation of nitrogen from the atmosphere to benefit the plants (Li et al. 2021). Rhizobacteria are microorganisms that live in plants' roots (rhizosphere) (Khatoon et al. 2020). They can reduce free nitrogen in the atmosphere to ammonia compounds (Pas Aksarah et al. 2015).

Previous studies showed that rhizobacteria were reported as plant growth promoters by fixing atmospheric nitrogen and producing hormones (Shridhar et al. 2012). However, further studies are still needed to determine their bio fertilization and biostimulant activity in various rice fields agro-ecosystem conditions. Israwan et al. (2015) reported that the surrounding environment strongly influences bacterial strains' ability to survive and produce 
metabolites. Munif et al. (2012) also reported that environmental factors such as soil properties, organic matter present, cultivation techniques, fertilization, and pesticide application affect bacterial strain. The same microbe species from different places do not necessarily have the same potential.

Rice fields in Indonesia consist of irrigated, rainfed, tidal, and lowland soil, with a total area of 8.1 million ha (Widiastuti 2017). In South Sulawesi, it is dominated by irrigated and rainfed fields. Therefore, this research aims to determine the bacteria characteristics from two wetland ecosystems (rainfed and irrigated) in South Sulawesi, which can fix nitrogen and produce IAA (Indole Acetic Acid). These bacteria can be recommended as good biofertilizers and bio stimulating agents to develop environmentally friendly and sustainable rice cultivation.

\section{MATERIALS AND METHODS}

\section{Study area}

This research was conducted from July to October 2019 at the Laboratory of Soil Microbiology, Department of Soil Science, Faculty of Agriculture, Hasanuddin University, Makassar, Indonesia. Soil samples were collected from six districts in South Sulawesi. Three samples from rainfed rice field in Gowa Regency (119²2'30.202"E; 5³4'6.423"S), Pangkep (119'30'33.005"E; 456'33.936"S), and Barru (119³5'28.889"E; 4³3'8.955"S). Three other samples from irrigated rice fields in Takalar $\left(119^{\circ} 23^{\prime} 1.499^{\prime \prime} \mathrm{E}\right.$; $\left.5^{\circ} 12^{\prime} 51.978^{\prime \prime S}\right)$, Maros (119²9'36.983"E; 5¹2'11.804"S, ) and Sidrap $\left(119^{\circ} 39^{\prime} 51.033^{\prime \prime E} ; 3^{\circ} 28^{\prime} 59.109^{\prime \prime S}\right)$ respectively (Figure 1). Soil samples were collected from roots of 25-40 days old of healthy rice in the depth of $0-20 \mathrm{~cm}$ at five points with an $\mathrm{X}$ pattern for each location. It was transferred into paper envelopes labeled according to the location, and the mixture was composited. Samples were taken to the laboratory using a cool box for immediate analysis (Kesaulya et al. 2015).

\section{Isolation and characterization of nitrogen fixating bacteria}

The isolation of Nitrogen-fixing bacteria was performed using Burk's N-free media (Park et al. 2005). Burk's N-free solid medium contained $20 \mathrm{~g}$ of sucrose, $0.64 \mathrm{~g}$ of $\mathrm{K}_{2} \mathrm{HPO}_{4}$, $0.16 \mathrm{~g}$ of $\mathrm{KH}_{2} \mathrm{PO}_{4}, 0.20 \mathrm{~g}$ of $\mathrm{MgSO}_{4}{ }_{7} \mathrm{H}_{2} \mathrm{O}$, and $0.20 \mathrm{~g}$ of $\mathrm{NaCl}, 0.05 \mathrm{~g}$ of $\mathrm{CaSO}_{4 \cdot 2} \mathrm{H}_{2} \mathrm{O}, 5 \mathrm{~mL}$ of $\mathrm{Na}_{2} \mathrm{MoO}_{4 \cdot 2} \mathrm{H}_{2} \mathrm{O}$ $(0.05 \%), 5 \mathrm{~mL}$ of $\mathrm{FeSO}_{4.7} \mathrm{H}_{2} \mathrm{O}(0.3 \%), 21 \mathrm{~g}$ of agar and $1000 \mathrm{~mL}$ of aqua dest (Hartono and Oslan Jumadi 2014). Serial sample dilution was carried out by grinding 1 gram of soil using a mortar until it was finely ground and then added with $10 \mathrm{~mL}$ of distilled water while stirring till it became a homogeneous solution. Furthermore, graded dilutions from $10^{-1}$ to $10^{-6}$ were carried out by taking $1 \mathrm{~mL}$ of the mixture using a pipette. Then, it was placed in the first test tube containing $9 \mathrm{~mL}$ of sterile distilled water, shaking it until it was consistent in composition using a vortex. It was referred to as the first dilution $\left(10^{-1)}\right.$. This procedure was repeated until $10^{-6}$ (the $6^{\text {th }}$ test tube). $0.1 \mathrm{~mL}$ of the diluted soil samples $10^{-3}, 10^{-4}, 10^{-5}$, and $10^{-6}$ ) were cultured on the Burk's medium using a triangle spreader rod and incubated for 24 hours at room temperature. Single colonies that grew on the growth media were then cultured by streaking on NA medium and purified 3 times. Pure colonies that grew with different appearances were characterized morphologically. It was performed according to the method proposed by Cappuccino and Sherman (2011).

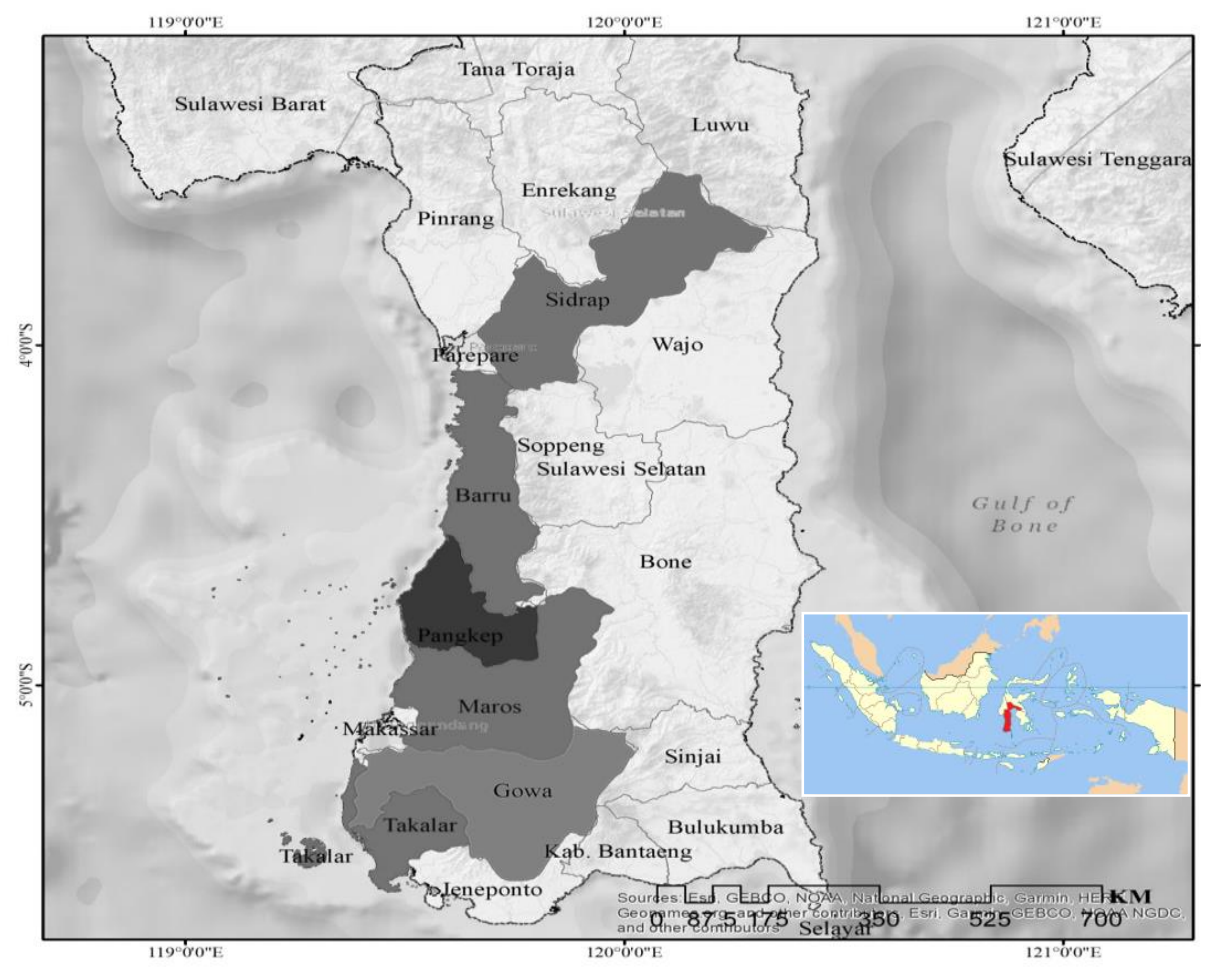

Figure 1. Location for rice rhizosphere sampling in South Sulawesi, Indonesia 


\section{Gram test}

The Gram test was carried out using the procedure by Pambudi et al. (2017). One loop full of bacterial isolates was taken using a loop needle and placed on an object glass that had been dripped with $10 \mu \mathrm{L}$ of $3 \% \mathrm{KOH}$ (Potassium Hydroxide) then stirred repeatedly. If the mixture of bacteria suspension and $\mathrm{KOH}$ suspension becomes markedly viscid or forms a gel within 5 to $60 \mathrm{~s}$, the isolate is classified as Gram-negative (-). If no gelling is observed, the isolate is classified as Gram-positive (+).

\section{Catalase test}

Catalase test was carried out according to the method by Suhartanti et al. (2010) with modification. This test was conducted to determine the ability of microbes to degrade hydrogen peroxide $\left(\mathrm{H}_{2} \mathrm{O}_{2}\right)$. One loop full of pure single colony culture was smeared on a previously dripped slide with two drops of $3 \% \mathrm{H}_{2} \mathrm{O}_{2}$. A positive reaction was characterized by the emergence of gas bubbles from free oxygen.

\section{The nitrogen fixation ability test}

The bacterial ability to fix nitrogen qualitatively was tested on Burk's N-free liquid media according to the method described by Park et al. (2005). Bacterial isolates were grown on Burk's $\mathrm{N}$-free media in glass bottles and placed in an orbital shaker for 24 hours at $28^{\circ} \mathrm{C}$.

The total $\mathrm{N}$ content of bacterial cultures was measured quantitatively using the Kjeldahl method (Rao 2010; Ramadhan and Tiwow 2016). As much as $5 \mathrm{~mL}$ of supernatant was put into the digestion tube and added $1 \mathrm{~g}$ of a mixture of selenium and $3 \mathrm{~mL}$ of concentrated sulfuric acid $\left(\mathrm{H}_{2} \mathrm{SO}_{4}\right)$ and digested for $3-4$ hours at $35^{\circ} \mathrm{C}$ until white steam comes out. Furthermore, the tube was removed and cooled down. Then, the extract was diluted with distilled water to $50 \mathrm{~mL}$ and shaken until homogeneous. The extract was allowed to stand for 24 hours for the particles to settle. The extract was transferred into the Erlenmeyer flask as a boiling flask containing $10 \mathrm{~mL}$ of $1 \%$ boric acid and 3 drops of Conway indicator (red-colored) and connected to a distillation device. Ten $\mathrm{mL}$ of $40 \% \mathrm{NaOH}$ was added to the boiling flask closed immediately. The distillation process was carried out until the container's volume reached 50 - 75 $\mathrm{mL}$ (green). The nitrogen content $(\%)$ was then calculated using the formula:

$$
\text { Nitrogen Level }(\%)=\frac{\{(v c-v b) \times N \times b s t N\}}{c} \times 100 \%
$$

Where:

Vc : Distillation titration example

$\mathrm{Vb}$ : Blank

$\mathrm{N}$ : Normality of $\mathrm{H}_{2} \mathrm{SO}_{4}$ standard solution

bst $\mathrm{N}$ : nitrogen equivalent weight (14)

$\mathrm{C}$ : mass of the sample

100 : conversion to $\%$

\section{The IAA production test of rhizobacteria}

The ability of rhizobacteria to produce IAA hormone was tested using a spectrophotometer. The microorganisms were cultured on Nutrient Agar (NA) media contained 200 ppm L-tryptophan. Then, $10 \mathrm{~mL}$ of the bacterial isolate was taken and placed in a $15 \mathrm{~mL}$ centrifuge tube and was centrifuged at $8000 \mathrm{rpm}$ for 10 minutes. Two $\mathrm{mL}$ of supernatant was taken out and placed in a test tube and added with 2 drops of orthophosphoric acid and $4 \mathrm{~mL}$ of Salkowski's reagent (Glickman and Dessaux 1995). Furthermore, it was incubated in a dark room for 24 hours. The change in color to pink indicated the microbe's ability to produce auxin. The pink color is caused by the reaction between Salkowski's reagent and the hormone. The optical density was measured at a wavelength of $535 \mathrm{~nm}$ using a UV-VIS spectrophotometer (Genesys IOS UV 840208100). The concentration of IAA was calculated using a linear regression equation from the IAA standard curve (Kesaulya et al. 2015; Israwan and Ardyati 2015).

\section{RESULTS AND DISCUSSION}

\section{Isolation and characterization of nitrogen-fixing bacteria from rice rhizosphere}

Twenty bacterial isolates with the potential to fix nitrogen from 6 sampling locations had various morphological and biochemical characteristics (Table 1). The ability of bacteria to fix nitrogen was confirmed by growing them on Burk's N-free media so that only bacteria with the ability to attach $\mathrm{N}$ that grow on it (Stella and Suhaimi 2010). Table 1. shows that 13 isolates were collected from rainfed rice fields (Gowa, Pangkep, Barru), and 7 isolates were from irrigated rice fields (Takalar, Maros, Sidrap).

Colonies with moderate-sized dominated the collected bacteria. Colony sizes ranging from $2.0 \mathrm{~mm}$ to $4.0 \mathrm{~mm}$ (small to large). The shape was dominated by irregular shapes (13 isolates), 6 rhizoids, and 1 with a circular form. The physical properties based on the edges varied widely; there were some with lobate, filamentous, entire, serrated, and undulate sides. The grouping on elevation showed that 10 isolates had umbonate elevation and the other 10 isolates had altitude. Furthermore, the color was dominated by cream and beige; the rest were white and yellowish. However, the morphological and biochemical characters cannot be used to identify the tested isolates.

Gram test results showed that 13 isolates were Gramnegative, and 7 isolates were Gram-positive (+) bacteria. The results of the catalase test showed that all nitrogenfixing bacteria were catalase positive. It was indicated by the presence of gas bubbles from free oxygen that produced when the microbe secrete catalase to break down hydrogen peroxide into water and oxygen (Pulungan and Tumangger 2018). Hydrogen peroxide $\left(\mathrm{H}_{2} \mathrm{O}_{2}\right)$ is poisonous to bacteria's metabolic system when they cannot degrade the chemical into other harmless compounds (Prathama et al. 2018). However, this is also achievable when a catalase enzyme is available without bacteria (Cappuccino and Sherman 2011). 
Table 1. The morphological and biochemical characteristics of bacteria isolated from rice rhizosphere at six rice fields in South Sulawesi, Indonesia

\begin{tabular}{|c|c|c|c|c|c|c|c|}
\hline \multirow{2}{*}{$\begin{array}{l}\text { Isolate } \\
\text { code }\end{array}$} & \multicolumn{5}{|c|}{ Colony morphology } & \multirow{2}{*}{$\begin{array}{c}\text { Gram } \\
(+/-)\end{array}$} & \multirow{2}{*}{$\begin{array}{c}\text { Catalase } \\
(+/-)\end{array}$} \\
\hline & Size & Form & Edge & Elevation & Color & & \\
\hline NG1 & Moderate & Irregular & Lobate & Raised & Cream & - & + \\
\hline NG4 & Moderate & Irregular & Entire & Umbonate & Cream & - & + \\
\hline NG5 & Moderate & Irregular & Serrate & Raised & Beige & + & + \\
\hline NG7 & Moderate & Irregular & Lobate & Raised & Beige & + & + \\
\hline NG11 & Large & Rhizoid & Filamentous & Umbonate & Cream & - & + \\
\hline NT1 & Moderate & Irregular & Lobate & Raised & Cream & + & + \\
\hline NT2 & Moderate & Irregular & Entire & Raised & Beige & - & + \\
\hline NT3 & Large & Irregular & Serrate & Umbonate & White & - & + \\
\hline NS2 & Moderate & Irregular & Serrate & Umbonate & Cream & - & + \\
\hline NS13 & Small & Irregular & Lobate & Raised & Beige & + & + \\
\hline NP1 & Large & Rhizoid & Filamentous & Umbonate & Cream & + & + \\
\hline NP7 & Moderate & Rhizoid & Filamentous & Naik & Beige & - & + \\
\hline NP11 & Moderate & Irregular & Lobate & Umbonate & Cream & - & + \\
\hline NP12 & Moderate & Circular & Entire & Umbonate & Cream & - & + \\
\hline NM4 & Moderate & Circular & Undulate & Raised & White & + & + \\
\hline NM5 & Small & Irregular & Lobate & Umbonate & Yellow & - & + \\
\hline NB8 & Large & Rhizoid & Filamentous & Umbonate & White & + & + \\
\hline NB10 & Moderate & Rhizoid & Filamentous & Umbonate & Yellow & - & + \\
\hline NB12 & Moderate & Irregular & Serrate & Raised & Cream & - & + \\
\hline NB13 & Moderate & Rhizoid & Filamentous & Raised & White & - & + \\
\hline
\end{tabular}

Notes: NG: isolates collected from Gowa; NT: isolates from Takalar; NS: isolates from Sidrap; NP: isolates from Pangkep; NM: isolates from Maros; NB: isolates from Barru.
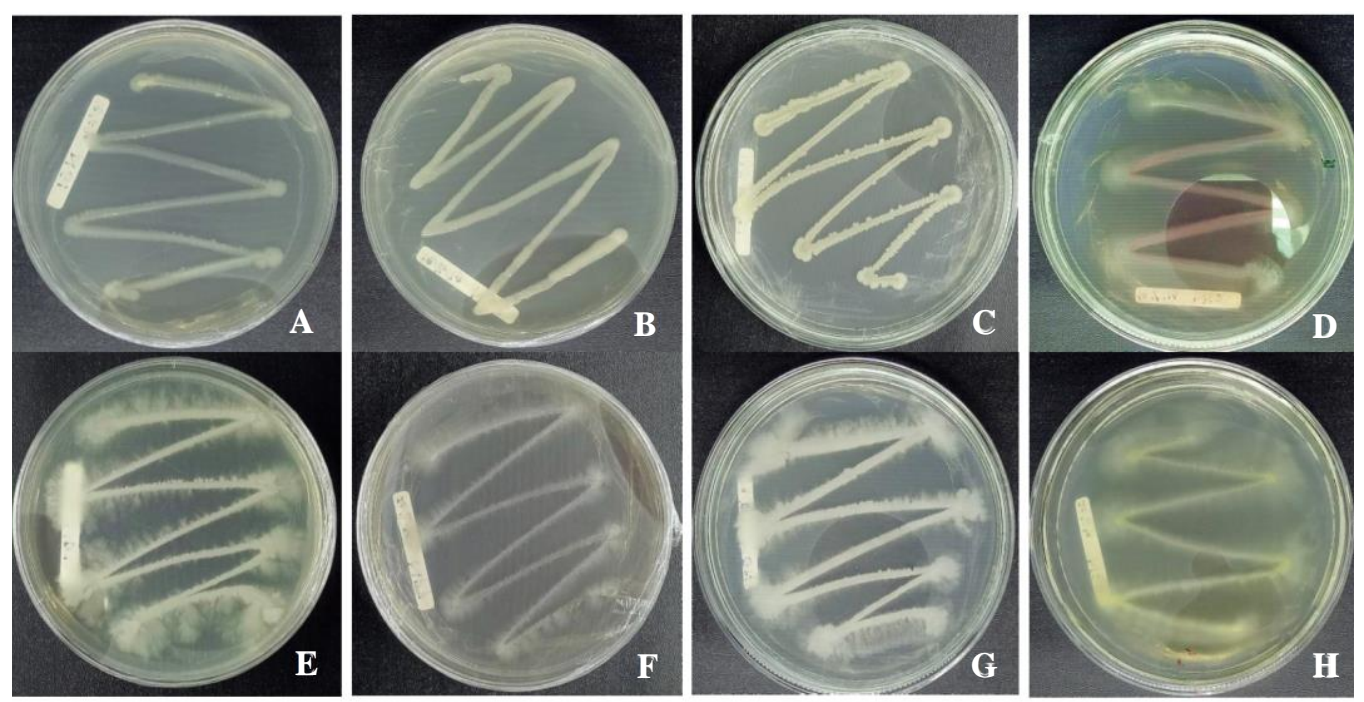

Figure 2. Pure culture of nitrogen-fixing bacteria from rice rhizosphere collected from several locations in South Sulawesi, Indonesia. A: NG1, B: NG4, C: NT1, D: NT2, E: NP1, F: NP7, G: NB8, H: NB10

\section{The ability of nitrogen fixation}

The quantitative test results of nitrogen-fixing ability were directly proportional to the qualitative examination using Burk's N-free media. All isolates were able to produce nitrogen in varying amounts (Figure 3). The NG4 isolate from Gowa had the highest ability to fix $\mathrm{N}$ $(0.157 \%)$, followed by NP11 isolate from Pangkep $(0.153 \%)$, and NT2 isolate from Takalar $(0.1510 \%)$. Meanwhile, the NM5 isolate from Maros produced the lowest $(0.132 \%)$. Varying ability to fix $\mathrm{N}$ caused by the different bacteria species and their capacity to perform this function.

\section{The ability of rhizobacteria to produce IAA}

Bacterial isolates were tested qualitatively and quantitatively for their ability to produce IAA. The results showed that all isolates could produce IAA. The qualitative test results (Figure 4) showed the variations in the color intensity of the supernatant. The result of qualitative analysis was directly proportional to the quantitative test. The NB13 isolate from Barru produced a more intense pink color and had the highest IAA concentration $\left(1,835 \mathrm{mg} \mathrm{L}^{-}\right.$ $\left.{ }^{1}\right)$, followed by NG11 isolate from Gowa $\left(1,630 \mathrm{mg} \mathrm{L}^{-1}\right)$ and NP1 isolate from Pangkep $\left(1,566 \mathrm{mg} \mathrm{L}^{-1}\right)$. Meanwhile, NT3 isolates had the lowest $\left(0.316 \mathrm{mg} \mathrm{L}^{-1}\right)$ (Figure 5). 


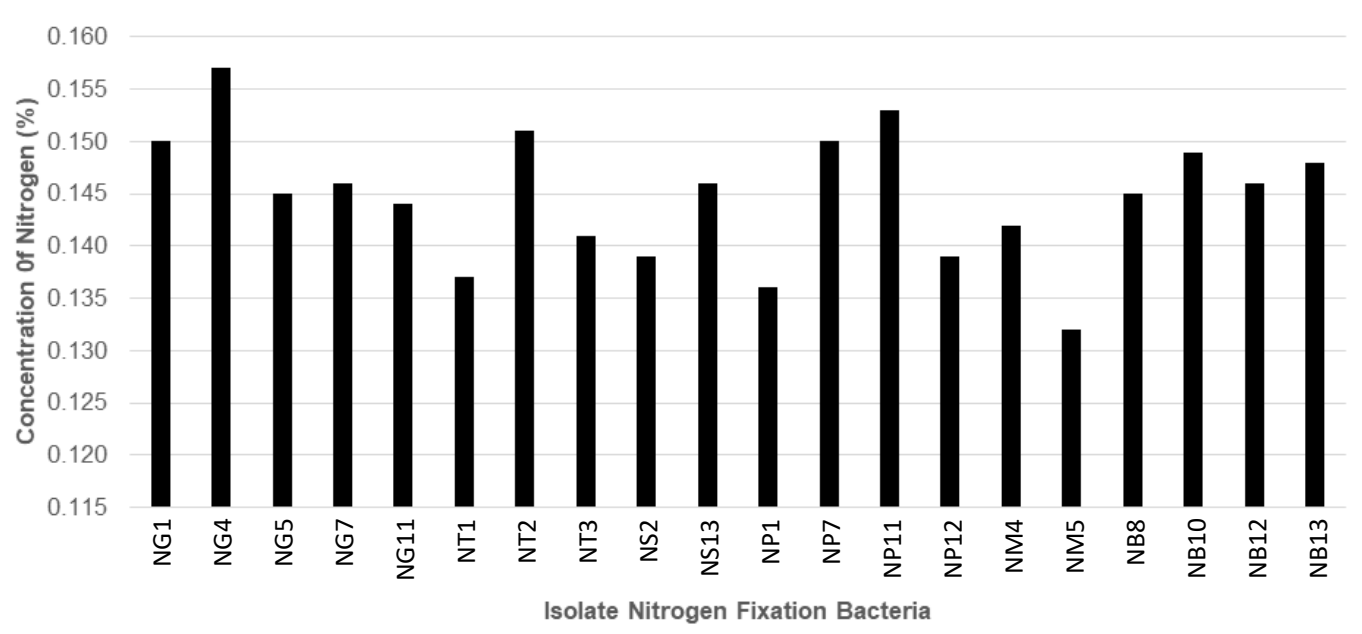

Figure 3. Nitrogen fixation ability of bacterial isolates from rice rhizosphere

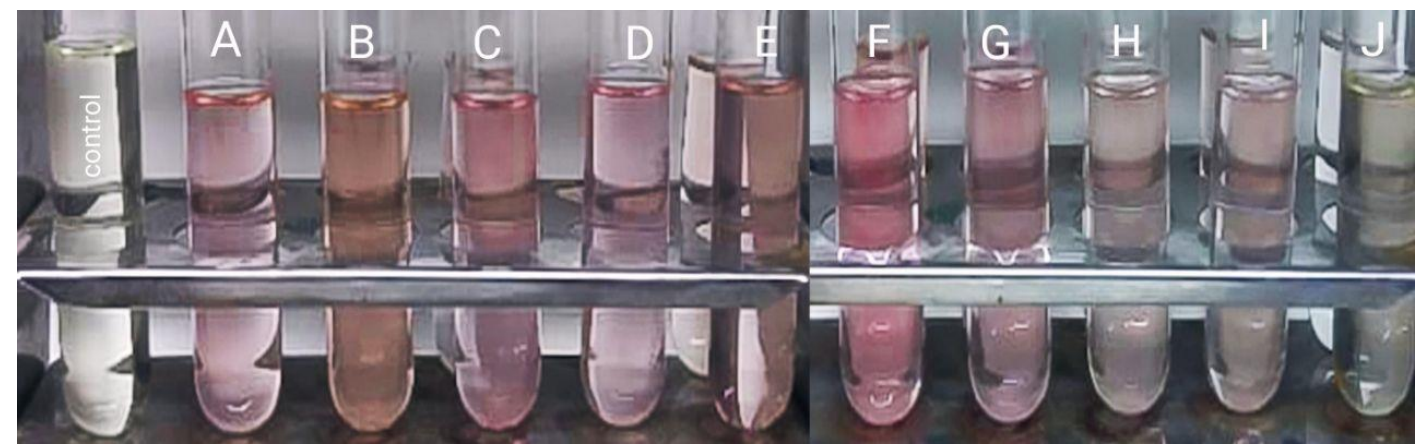

Figure 4. Qualitative analysis of the IAA production by bacterial isolates with Salkowski's reagent. Changes to pink color were determined in the supernatant of: A. NM5, B. NG11, C. NS12, D. NB10, E. NB13, F. NP1, G. NB12, H. NG1, I. NG4, J. NP7

This variation was due to the difference in the ability of the microorganisms to change tryptophan into IAA. According to Lestari et al. (2015), IAA-producing bacteria can be cultivated on growth media containing this amino acid, with the enzyme IAA oxidase. It was synthesized as a secondary metabolite under suboptimal growth conditions (Panigrahi et al. 2019). According to Carlos et al. (2016), L- tryptophan in the soil comes from root exudates or damaged cells.

\section{Discussion}

The diversity of the collected bacterial isolates indicated the variety of nitrogen-fixing bacteria. Table 1 showed that 13 isolates were collected from rainfed rice fields, and 7 isolates were from irrigated lands. The results were consistent with previous studies by Hartono and Oslan Jumadi (2014); Herwati et al. (2020); Sukmawati et al. (2020); Tarigan et al. (2013).

Morphological characteristics of the 20 collected bacteria differ from one another. Further analysis was still needed to determine the genus and species of these bacterial isolates. Based on the Gram test, 6 isolates were Gram-positive (+), and 14 isolates were Gram-negative (-). Grouping of bacteria by Gram test is the basis for identifying and classification of bacteria (Radji 2006). This difference was due to the cell wall structure. The cell wall structure of Gram-positive bacteria consists of peptidoglycan, while the cell wall structure of Gramnegative (-) consists of lipids (Sudewi et al. 2020). Rainfed rice fields were dominated by Gram-negative bacteria. The results of the catalase test showed that all isolates produce catalase. The catalase enzyme was essential for aerobic growth because $\mathrm{H}_{2} \mathrm{O}_{2}$, a respiratory enzyme, is toxic to microbial cells (Sahu et al. 2019). Non-pathogenic bacteria, both Gram-positive and Gram-negative, have a vital role as biocontrol agents in controlling plant diseases (Amaria et al. 2019). Gram-negative Azotobacter and Azospirillum are non-pathogenic. One species of Azotobacter, i.e., Azotobacter vinelandii, produces an anti-fungal that suppresses the development of Fusarium oxysporum, a causative agent of wilt disease (Hindersah et al. 2018).

Agro-ecosystems and technological inputs in rice fields affect bacterial diversity. The highest varieties were obtained in rainfed lands by $65 \%$ compared to irrigated fields with only $35 \%$. Kurniawati et al. (2013) reported that the highest diversity of microbial populations was obtained in rainfed rice fields by $37.5 \%$, in the swampy area by $31.75 \%$, and then $30.75 \%$ irrigated lands. 


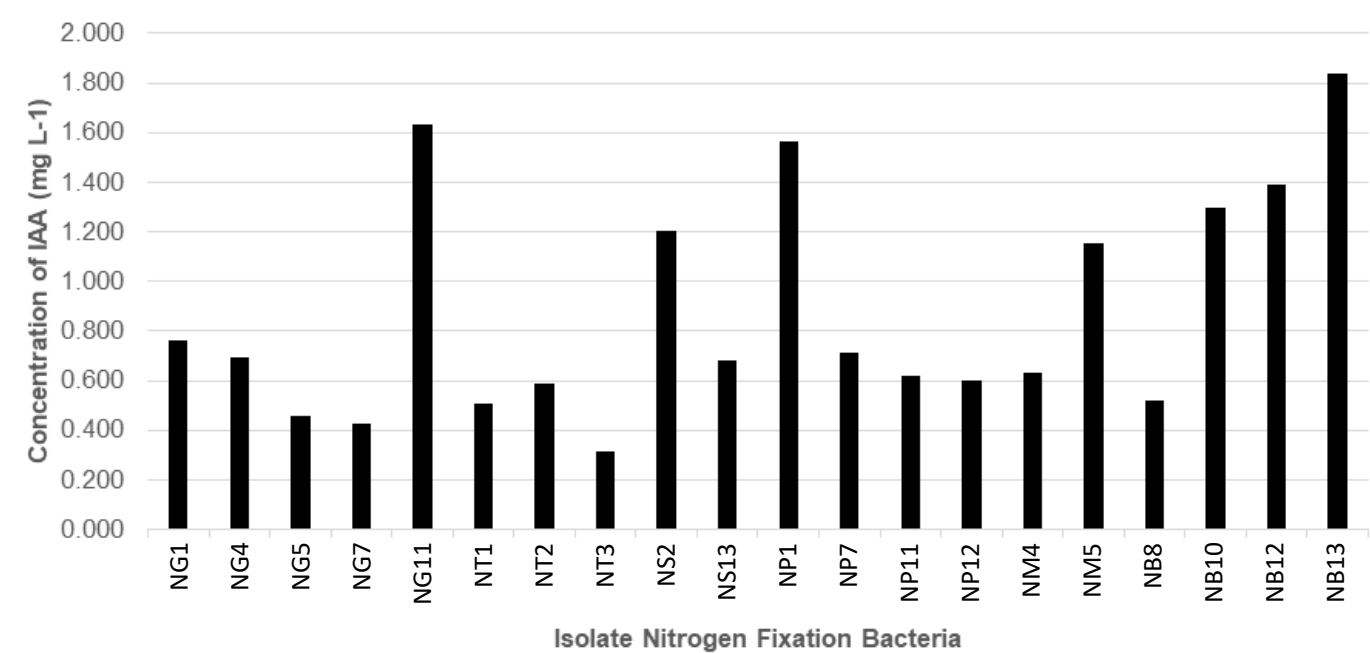

Figure 5. Quantitative analysis of IAA production by bacterial isolates using a UV-VIS spectrophotometer $535 \mathrm{~nm}$

All of the collected microorganisms were a nonsymbiotic nitrogen-fixing potential that capable of growing on $\mathrm{N}$-free media. The nitrogen-fixing ability was varied. NG4 isolate had the highest ability to fix nitrogen $(0.157 \%)$, followed by NP11(0.153\%) and NT2 $(0.150 \%)$. Meanwhile, the NM5 isolate produced the lowest nitrogen $(0.132 \%)$.

Nitrogen-fixing bacteria perform this function because they have a specific enzyme in the cell known as nitrogenase composed of two mutually supporting components: Fe and Mo-Fe protein (Geddes et al. 2015). Stella and Suhaimi (2010) stated that non-symbiotic bacteria in the rhizosphere of Gramineae plants, such as Azotobacter paspali and Beijerinckia spp, are aerobic groups that colonized the root surface. The isolates from rainfed ricefield usually have better nitrogen-fixing ability than that of irrigated fields. The irrigated field has a high level of intensive chemical $\mathrm{N}$ fertilizers, which reduces the diversity and activity of these microorganisms since it makes their work unnecessary (Martínez-Romero 2009).

A qualitative test of bacterial isolates' ability to produce IAA was carried out by observing the change in color of the supernatant to pink. The higher the color intensity, the higher the hormone concentration. Hormone concentrations vary due to the differences in agro-ecosystem conditions and cultivation techniques at the sampling locations. Israwan et al. (2015) stated that the surrounding environment greatly influences bacterial ability to survive and produce IAA. Munif et al. (2012) indicated that soil properties, organic matter, cultivation techniques, fertilization, and pesticide application affect the presence of bacteria.

The results showed that isolate NB13 from Barru produced a more intense pink color and had the highest IAA concentration $\left(1,835 \mathrm{mg} \mathrm{L}^{-1}\right)$, followed by NG11 from Gowa $\left(1,630 \mathrm{mg} \mathrm{L}^{-1}\right)$ and NP1 from Pangkep (1,566 mg L$\left.{ }^{1}\right)$. Meanwhile, the NT3 isolate had the lowest IAA concentration of $0.316 \mathrm{mg} \mathrm{L^{-1 }}$. Isolates with high IAA production were isolated from rainfed rice fields (Barru, Pangkep, and Gowa). It might be concluded that bacteria isolated from rainfed rice fields have a higher IAA production than those from irrigated rice fields. The IAA production was strongly influenced by biochemical characteristics and environmental factors (Numan et al. 2018). Rainfed fields are not flooded all year round so that allowing aerobic bacteria to grow. Moreover, agroecosystems and cultivation techniques also greatly influence an isolate's type and ability (Kurniawati et al. 2013). Intensive agricultural practices that utilize irrigation extensively and the increasing use of chemicals and heavy machinery causes degradation that affects biological life in the soil (Zalidis et al. 2002; Li J et al. 2015; Pereg et al. 2018).

This study concluded that microbes from rainfed rice fields in South Sulawesi were potential as biofertilizers and biostimulant agents than those from irrigated rice fields.

\section{ACKNOWLEDGEMENTS}

The authors are grateful to the LPDP/Indonesia Endowment Fund for Education for funding this research and all the parties involved in publishing this article.

\section{REFERENCES}

Amaria W, Kasim NN, Munif A. 2019. Kelimpahan populasi bakteri filosfer, rizosfer dan endofit tanaman kemiri sunan (Reutealis trisperma (Blanco) Airy Shaw), serta potensinya sebagai biokontrol. Tabaro 3 (1): 305-317. [Indonesian]

Cappuccino JG, Sherman N. 2011. Microbiology: A Laboratory Manual, 9th ed. Pearson, London.

Carlos MHJ, Stefani PVY, Janette AM, Melani, MSS, Gabriela PO. 2016. Assessing the effects of heavy metals in ACC deaminase and IAA production on plant growth-promoting bacteria. Microbiol Res 188 (2016): 53-61. DOI: 10.1016/j.micres.2016.05.001.

Dong L, Tong X, Li X, Zhou J, Wang S, Liu B. 2019. Some developments and new insights of environmental problems and deep mining strategy for cleaner production in mines. J Cleaner Prod 210: 1562-1578. DOI: 10.1016/j.jclepro.2018.10.291.

Geddes BA, Ryu MH, Mus F, Garcia Costas A, Peters JW, Voigt CA, Poole P. 2015. Use of plant colonizing bacteria as chassis for transfer 
of N2-fixation to cereals. Curr Opin Biotechnol 32: 216-222. DOI: 10.1016/j.copbio.2015.01.004.

Glickman E, Dessaux Y. 1995. A critical examination of the specificity of the Salkowski reagent for indolic compounds produced by phytopathogenic bacteria. Appl Environ Microbiol 61: 793-796.

Hartono, Jumadi O. 2014. Seleksi dan karakterisasi bakteri penambat nitrogen non simbiotik pengekskresi amonium pada tanah pertanaman jagung (Zea mays L.) dan Padi (Oryza sativa L.) Asal Kabupaten Barru, Sulawesi Selatan, Indonesia. Jurnal Sainsmat 3 (2): 143-153. [Indonesian]

Herwati A, Patandjengi B, Jayadi M, Masniawati. 2020. Isolation and characterization of nitrogen-fixing bacteria and producing IAA (Indole acetic acid) from rice rhizosphere from the Sopeng regency. Int J Pharm Res 13 (1): 808-815. DOI: 10.31838/ijpr/2021.13.01.138

Hindersah R, Kalay M, Talahaturuson A, Lakburlawal Y. 2018. Bakteri pemfiksasi nitrogen Azotobacter pada tanaman kacang panjang. Agric 30 (1): 25-32. DOI: 10.24246/agric.2018.v30.i1.p25-32. [Indonesian]

Israwan RF, Ardyati T. 2015. Eksplorasi bakteri pemfiksasi nitrogen non simbiotik penghasil IAA dan pelarut fosfat asal rhizosfer tanaman apel Kota Batu , Jawa Timur. Biotropika 3 (2): 55-59. [Indonesian]

Kesaulya H, Baharuddin, Zakaria B, Syaiful SA. 2015. Isolation and physiological characterization of PGPR from potato plant rhizosphere in medium land of Buru Island. Procedia Food Sci 3: 190-199. DOI: 10.1016/j.profoo.2015.01.021

Khatoon Z, Huang S, Rafique M, Fakhar A, Kamran MA, Santoyo G. 2020. Unlocking the potential of plant growth-promoting rhizobacteria on soil health and the sustainability of agricultural systems. J Environ Manag 273 (August): 111118. DOI: 10.1016/j.jenvman.2020.111118.

Kurniawati S, Muttaqin HK, Giyanto. 2013. Keragaman bakteri pada pertanaman padi di lahan sawah irigasi, tadah hujan dan rawa Ketahanan Pangan 259-266. [Indonesian]

Lestari P, Suryadi Y, Susilowati DN, Priyatno TP, Samudra IM. 2008. Karakterisasi bakteri penghasil asam indol asetat dan pengaruhnya terhadap vigor benih padi. Berita Biologi 14 (1): 19-28. [Indonesian]

Li J, Deng J, Gu Q, Wang K, Ye F, Xu Z, Jin S. 2015. The accelerated urbanization process: A threat to soil resources in eastern China. $\begin{array}{lllll}\text { Sustainability } & \text { (Switzerland) } 7 & \text { (6): 7137-7155. DOI: }\end{array}$ 10.3390/su7067137.

Li Y, Yuan L, Xue S, Liu B, Jin G. 2021. Artificial root exudates excite bacterial nitrogen fixation in the subsurface of mine soils. Appl Soil Ecol 157 (September 2020): 103774. DOI: 10.1016/j.apsoil.2020.103774.

Ma J, Bei Q, Wang X, Lan P, Liu G, Lin X, Liu Q, Lin Z, Liu B, Zhang Y, Jin H, Hu T, Zhu J, Xie Z. 2019. Impacts of Mo application on biological nitrogen fixation and diazotrophic communities in a flooded rice-soil system. Sci Total Environ 649: 686-694. DOI: 10.1016/j.scitotenv.2018.08.318

Martínez-Romero E. 2009. Coevolution in rhizobium-legume symbiosis. DNA Cell Biol 28 (8): 361-370. DOI: 10.1089/dna.2009.0863.

Munif A, Wiyono S, Suwarno S. 2012. Isolasi bakteri endofit asal padi gogo dan potensinya sebagai agens biokontrol dan pemacu pertumbuhan. Jurnal Fitopatologi Indonesia 8 (3): 57-64. DOI: 10.14692/jfi.8.3.57. [Indonesian]

Numan M, Bashir S, Khan Y, Mumtaz R, Shinwari ZK, Khan AL, Khan A, AL-Harrasi A. (2018). Plant growth promoting bacteria as an alternative strategy for salt tolerance in plants: A review. Microbiol Res 209 (Jan): 21-32. DOI:10.1016/j.micres.2018.02.003

Pambudi A, Susanti S, Priambodo, TW. 2017. Isolasi dan karakterisasi bakteri tanah sawah di Desa Sukawali dan Desa Belimbing, Kabupaten Tangerang. Al-Kauniyah: Jurnal Biologi 10 (2): 105-113. DOI: 10.15408/kauniyah.v10i2.4907. [Indonesian]

Panigrahi S, Mohanty S, Rath CC. 2019. Characterization of endophytic bacteria Enterobacter cloacae MG00145 isolated from Ocimum sanctum with Indole Acetic Acid (IAA) production and plant growth promoting capabilities against selected crops. South Afr J Bot 000: 110. DOI: $10.1016 /$ j.sajb.2019.09.017

Park M, Kim C, Yang J, Lee H, Shin W, Kim S, Sa T. 2005. Isolation and characterization of diazotrophic growth promoting bacteria from rhizosphere of agricultural crops of Korea. Microbiol Res 160 (2): 127-133. DOI: $10.1016 /$ j.micres.2004.10.003

Pas Aksarah A, Sopandie D, Trikoesoemaningtyas, Santosa DA. 2015 Aplikasi konsorsium mikroba filosfer dan rizosfer untuk meningkatkan pertumbuhan dan hasil tanaman padi. Institut Pertanian Bogor (IPB) Kampus, 15-24. [Indonesian]

Pereg L, Morugán-Coronado A, McMillan M, García-Orene F. 2018.
Restoration of nitrogen cycling community in grapevine soil by a decade of organic fertilization. Soil Tillage Res 179 (July 2017): 1119. DOI: $10.1016 /$ j.still.2018.01.007

Prathama Y, Nelvia N, Amri AI. 2018. Pemberian amelioran dan isolat bakteri fiksasi nitrogen non simbiotik untuk meningkatkan pertumbuhan dan serapan $\mathrm{N}$ tanaman padi gogo (Oryza sativa $\mathrm{L}$.) pada medium ultisol. Jurnal Solum 15 (2): 40. DOI: lum.15.2.4049.2018. [Indonesian]

Pulungan AS, Tumangger, DE. 2018. Isolasi dan Karakterisasi bakteri endofit penghasil enzim katalase dari daun Buasbuas (Premna pubescens Blume) Isolation and characterization of endophytic bacteria producing catalase enzyme from Buasbuas (Premna pubescens Blume) leaves. Jurnal Biologi Lingkungan, Industri, Kesehatan 5 (1): 72-80. DOI: 10.31289/biolink.v5i1.1665 [Indonesian]

Radji M. 2006, Penuntun Praktikum Mikrobiologi Farmasi, Edisi 2, Departemen Farmasi, FMIPAUI, Depok. [Indonesian]

Ramadhan S dan Tiwow VMA 2016. Analisis kadar unsur nitrogen (N) dan posforus (P) dalam lamun (Enhalus acoroides) di wilayah perairan Kabupaten Donggala. J Akad Kimia 5 (1): 37-43. DOI: 10.22487/j24775185.2016.v5.i1.7998

Rao S. 2010. Mikroorganisme tanah dan pertumbuhan tanaman. terjemahan Herawati Susilo. Universitas Indonesia (UI-Press), Jakarta. [Indonesian]

Rascio N, La Rocca N. 2018. Biological nitrogen fixation. Encyclopedia Ecol 2 (Jul): 264-279. DOI: 10.1016/B978-0-444-63768-0.00685-5

Sahu AK, Kar BRK, Sahu SS, Achary, Pragnya P, Harichandan PS. 2019. Isolation, characterization of endophytic bacteria from Psidium guajava plant and screening of their antibiotic activities. Int J Res Appl Sci Eng Technol 7 (1): 345-355. DOI: 10.22214/ijraset.2019.1061.

Shridhar BS, Shrimant Shridhar B. 2012. Review: Nitrogen fixing microorganisms. Int J Microbiol Res 3 (1): 46-52. DOI: 10.5829/idosi.ijmr.2012.3.1.61103.

Stella M, Suhaimi M. 2010. Selection of suitable growth medium for freeliving diazotrophs isolated from compost. J Trop Agric Fd Sc 38 (2): 211-219.

Sudewi S, Ala A, Baharuddin, Farid M. 2020. The isolation, characterization endophytic bacteria from roots of local rice plant Kamba in, Central Sulawesi, Indonesia. Biodiversitas 21 (4): 16141624. DOI: $10.13057 /$ biodiv/d210442.

Suhartanti M, Sarjono PR, Aminin ALN. 2010. Studi filogeni dan uji potensi enzim ekstraseluler (amilase, $\beta$-galaktosidase, protease, katalase) Isolat Alicyclobacillus sp. Gedong Songo. Jurnal Kimia Sains dan Aplikasi 13 (3) 80-87. DOI: 10.14710/jksa.13.3.80-87. [Indonesian]

Sukmawati, Ala A, Patandjengi B, Gusli S. 2020. Exploring of promising bacteria from the rhizosphere of maize, cocoa and lamtoro. Biodiversitas 21 (12): 5665-5673. DOI: 10.13057/biodiv/d211224.

Sun X, Zhong T, Zhang L, Zhang K, WuW. 2019. Reducing ammonia volatilization from paddy field with rice straw derived biochar. Sci Total Environ 660: 512-518. DOI: 10.1016/j.scitotenv.2018.12.450.

Tahovská K, Kaňa J, Bárta J, Oulehle F, Richter A, Šantrůčková H. 2013. Microbial $\mathrm{N}$ immobilization is of great importance in acidified mountain spruce forest soils. Soil Biol Biochem 59: 58-71. DOI: 10.1016/j.soilbio.2012.12.015.

Tarigan RS, Jamilah IDE. 2013. Seleksi bakteri penambat nitrogen dan penghasil hormon IAA (Indole Acetic Acid) dari rizosfer tanah perkebunan kedelai (Glycine max L.). Saintia Biologi 1 (2): 42-48. [Indonesian]

Vinten AJA, Ball BC, O'Sullivan MF, Henshall JK. 2002. The effects of cultivation method, fertilizer input and previous sward type on organic $\mathrm{C}$ and $\mathrm{N}$ storage and gaseous losses under spring and winter barley following long-term leys. J Agric Sci 139 (3): 231-243. DOI: $10.1017 /$ S0021859602002496.

Widiastuti F. 2017. Lahan sawah sebagai pendukung ketahanan pangan serta strategi pencapaian kemandirian pangan. Lahan Sawah Sebagai Pendukung Ketahanan Pangan Serta Strategi Pencapaian Kemandirian Pangan 8 (3): 17-30. DOI: 10.2018/jsdl.v8i3.6479. [Indonesian]

Witte CP. 2011. Urea metabolism in plants. Plant Sci 180 (3): 431-438. DOI: $10.1016 / \mathrm{j}$.plantsci.2010.11.010.

Zalidis G, Stamatiadis S, Takavakoglou V, Eskridge K, Misopolinos N. 2002. Impacts of agricultural practices on soil and water quality in the Mediterranean region and proposed assessment methodology. Agric Ecosyst Environ 88 (2): 137-146. DOI: 10.1016/S01678809(01)00249-3. 